\title{
BUILDING INFORMATION MODEL AS A POSSIBILITY FOR DIGITAL RECONSTRUCTION OF THE BUILDINGS OF RURAL ARCHITECTURE
}

\author{
Z. Poloprutský $1, *$ \\ ${ }^{1}$ CTU in Prague, Faculty of Civil Engineering, Thákurova 7/2077, 16629 Prague 6, Czech Republic - \\ zdenek.poloprutsky@fsv.cvut.cz
}

Commission V, WG V/7

KEY WORDS: $19^{\text {th }}$ and $20^{\text {th }}$ century, Building Information Model (BIModel), Computer Aided Design (CAD), Close range photogrammetry, Cultural heritage, Geographic Information System (GIS), Metric Survey Documentation

\begin{abstract}
:
This paper deals with the use of Historical Building Information Modelling for digital reconstruction of buildings of rural architecture. The final Building Information Model (BIModel) can be used for research purposes such as Artistic and Historical Research, Building Archaeology Survey, etc., or can be used as basis for building restoration. The aim of the BIModel is to provide a reliable basis for future work.

This paper presents practical experience gained during the implementation of the grant project "The Transformation of Rural Architecture with Emphasis on the Development of the $19^{\text {th }}$ and $20^{\text {th }}$ Centuries", No. DG16P02H023. In the course of the project, datasets were collected from various sources and various types, usually photo documentation, cadastral maps, metric survey documentation, texts, etc. The interconnection of the datasets had to be ensured for future work. Therefore, solutions were sought to achieve this goal. Usually, complications occurred in sharing and exchanging data formats, georeferencing, selecting of resolution or Level of Detail (LoD), etc. In these cases, software tools and workflows were sought for integration between CAD or GIS, and vice versa.
\end{abstract}

\section{INTRODUCTION}

This paper presents practical experience gained during the implementation of the grant project "The Transformation of Rural Architecture with Emphasis on the Development of the $19^{\text {th }}$ and $20^{\text {th }}$ Centuries", No. DG16P02H023. The main objective of the project is to present the historical and artistic values of rural architecture as a national cultural heritage that needs to be protected. Attention is paid to the urban development of selected villages in all regions of the Czech Republic, as well as various examples of valuable buildings. Outputs of the research project are continuously presented to professionals and general public - through thematic exhibitions (Hůrková and Mezihoráková, 2018), book publications (Hůrková and Mezihoráková, 2016; Vlček, 2017), professional articles (Hodač and Zemánková, 2018; Poloprutský, 2018; Poloprutský et al., 2017) and workshops for students (Hůrková and Mezihoráková, 2017).

For the analysis of urban development of the surveyed villages, researchers use historical maps, mostly cadastral, which represent an important source of information. Using Geographic Information Systems (GIS), analytical map outputs are drafted that depict the development of the buildings in the village, or in its selected parts. Basic type of an analytical map output shows a state of development in all time periods processed. Another type of an analytical map output shows in detail the development of buildings in the second half of the $19^{\text {th }}$ century. See (Poloprutský, 2018; Poloprutský et al., 2017). The rural architecture is very diverse, as shown in Figure 1, Figure 2 and Figure 3.

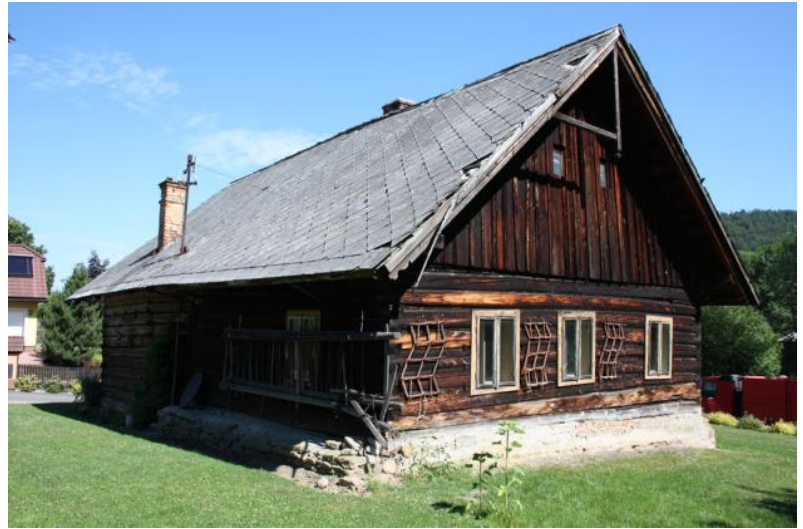

Figure 1. Example of an examined building, Vigantice (Vsetín dist.)

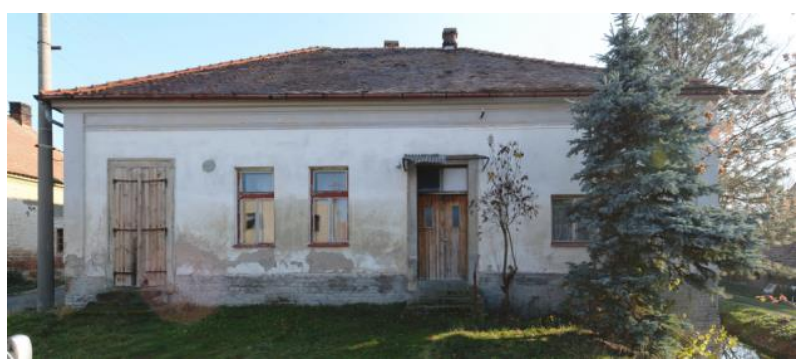

Figure 2. Example of an examined building, Úhřetická Lhota (Pardubice dist.)

* Corresponding author 
Furthermore, the researchers use the method of Artistic and Historical Research, for which it is advantageous to be supported by additional documentation. In this project it is photographic documentation (Bezděk and Frouz, 2014) of selected villages and rural buildings. Furthermore, it is metric survey documentation of examined buildings (Poloprutský, 2018; Veselý, 2014).

As part of the project, selected rural buildings are documented with ground plans, see Figure 4, and point clouds, see Figure 5. Point cloud is processed via close range photogrammetry (Brejcha et al., 2015; Luhmann et al., 2014). The final output are digital spatial models of rural buildings, which are then interactively presented on the project website, see (Poloprutský, 2018).

\section{DATA PROCESSING}

Analytical map outputs are processed with the support of GIS software, specifically ArcMap 10.6. Drawings of the ground plans are made with the support Computer Aided Design (CAD) software, specifically MicroStation, CONNECT Edition. Interconnection of the analytical map outputs with ground plan drawings is ensured via the geodetic reference system S-JTSK ${ }^{1}$. The drawings are connected to the S-JTSK using the current cadastral map, whose digital form is freely available through Atom download service (Czech Office for Surveying, Mapping and Cadastre, 2016).

Close range photogrammetry is realized through Agisoft PhotoScan software. Point clouds are edited in CloudCompare software. Some software, such as CloudCompare, are not recommended to work with high values of coordinates, over $1000 \mathrm{~m}$. This is the case with JTSK, see Figure 4. In this case, it is advisable to define a so-called global shift, i.e. reduction of coordinate values.

At the beginning of the project, it was necessary to select workflows and technologies for 3D model processing of the examined buildings. Given that the project schedule is limited - by human, time and financial resources - it was necessary to proceed with simplified metric survey documentation of buildings in situ, i.e. without using geodetic measurements. Therefore, the 3D models of examined buildings are, to a reasonable extent, simplified (Poloprutský, 2018).

At the beginning of the project, we chose between three possible approaches to the processing of 3D models of the examined buildings:

1. Mesh - Digital Surface Model (DSM) created from a point cloud

2. CAD approach - 3D solid model created from drawings and point clouds

3. HBIM approach - Building Information Model (BIModel ${ }^{2}$ ) - main attention is paid to geometric component

\subsection{Mesh processing}

In this solution, meshing of point cloud was done independently in Agisoft PhotoScan software and Geomagic Studio 2012 software. In Figure 5, empty spots are visible, mainly found on roofs and their ridges, adjacent vegetation and monochrome areas.

1 Datum of Uniform Trigonometric Cadastral Network, EPSG: 5514 - mandatory geodetic reference system for the Czech Republic

${ }^{2}$ According to (BIMe Initiative, 2017).

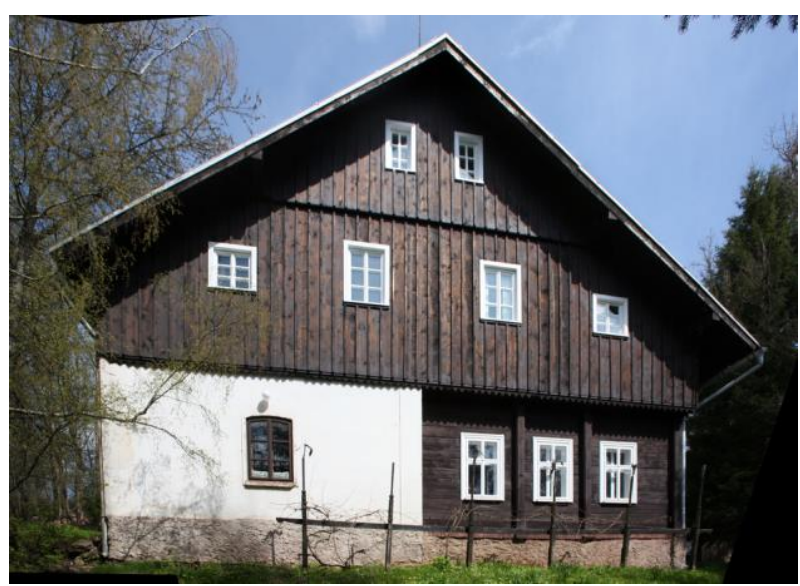

Figure 3. Example of an examined building, Rudník - Bokov (Trutnov dist.)

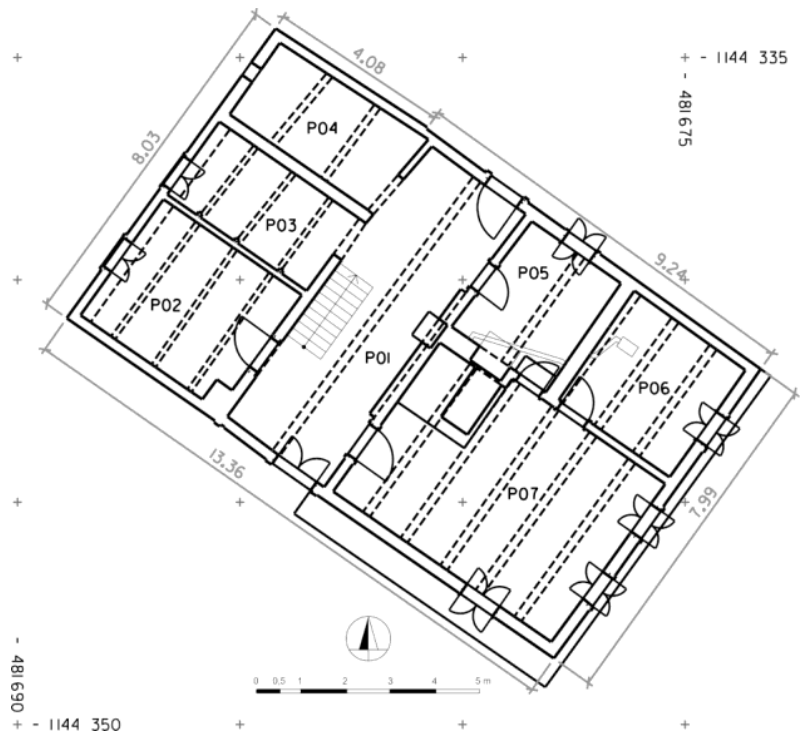

Figure 4. Example of the final ground plan of the examined building, Vigantice (Vsetín dist.)

These reasons negatively affect the quality of the final point cloud - empty spots in dense point cloud and noise - and the continuing DSM, see Figure 6. Therefore, this variant of 3D modelling has been abandoned.

\subsection{CAD approach}

In this solution, the data processing continued in MicroStation software. MicroStation allows to connect or import data files of various types - drawings (vector or raster), point clouds, 3D models, etc., which can then be georeferenced.

At the beginning of the $3 \mathrm{D}$ modelling process, it is necessary to properly define the coordinate system of a spatial model in which 3D modeling will take place. In georeferencing process, the congruent transformation ${ }^{3}$ was applied. For georeferencing of raster data, Raster manager function is available. For georeferencing of other data types, it is usually sufficient to use a combination of functions - shift, rotate and scale.

Currently, CAD software enable direct vector drawing and modeling of spatial objects. For this purpose, CAD software contain specialized functions. It also supports the layering of a

\footnotetext{
${ }^{3}$ It is the similarity transformation (Luhmann et al., 2014),
} which preserves dimensions, i.e. $\mathrm{m}=1$. 
drawing or 3D model into thematic data layers. Therefore, the individual 3D model can be divided into layers that correspond to individual structural parts of the spatial object. An example of the final 3D model of the examined building is shown in Figure 7.

The advantage of this approach is that it allows to create virtually any unique 3D model.

The disadvantage of this approach is that later editing, such as extensions or additions, can be more difficult.

\subsection{HBIM approach}

In this solution, the data processing continued in Revit software. Revit allows to connect or import data files of various types - drawings (vector or raster), point clouds, 3D models, etc., which can then be georeferenced.

At the beginning of the HBIM process, it is necessary to properly define the coordinate system of a BIModel in which modelling will take place. For georeferencing of the data, it is usually sufficient to use a combination of functions - shift, rotate and scale. Furthermore, Revit software allows to define how to connect the underlying data, mostly it is possible via shared coordinates. The disadvantage is that Revit limits the scope of the model. In cases with high coordinate values, i.e. over $1000 \mathrm{~m}$, it is necessary to define the so-called global shift, i.e. reduce the corresponding coordinates, see Chap. 2.

Currently, BIM software enables parametric object-oriented modelling of 3D objects. This technique is based on the use of predefined libraries and basic structural elements. For this purpose, software platforms include specialized features.

Since the BIM approach is based on parametric object-oriented building modelling, it can be successfully applied to historic buildings, so-called HBIM approach. An essential part of this approach is the creation of libraries of historical structures, socalled components (Baik et al., 2014; Tommasi et al., 2016). Subsequently, individual types of components can be individually placed in the BIModel and their dimensions can be adjusted. Typically these are windows and doors, see Figure 8 and Figure 9.

The advantage of this approach is that it allows to create any $3 \mathrm{D}$ model extended with additional attributes, i.e. information. In BIModels it is possible to distinguish individual types of building structures, respectively. components, and their parts. The dimensions of the components can then be changed, while their spatial superposition remains.

The disadvantage of this approach is that the existence of appropriate libraries of historical structures is assumed. In cases, where these libraries do not exist, it is necessary to create them on the basis of metric survey documentation, Building Archaeology Survey (Beránek and Macek, 2015) etc. Then, it is so-called HBIM approach.

\subsection{Summary}

In this project, the most common metric survey documentation consists of vector drawings and point clouds created from close range photogrammetry. For vector drawings and 3D models, it is best to use the DXF format as a swap-format, the TXT format is best for point clouds. For raster drawings, the JPEG format is usually sufficient, the resolution of the imported image is important in this case.

Both, the CAD and HBIM approaches support the creation of a digital elevation model (DEM) in the vicinity of the modeled building, see Figure 7. In both approaches, DEM can be imported into the model as a separate data layer.

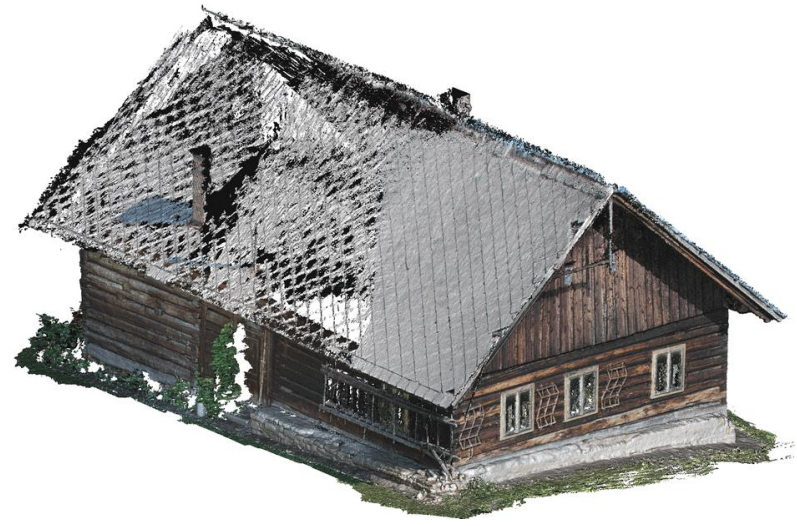

Figure 5. Example of the final point cloud of the examined building, Vigantice (Vsetín dist.)

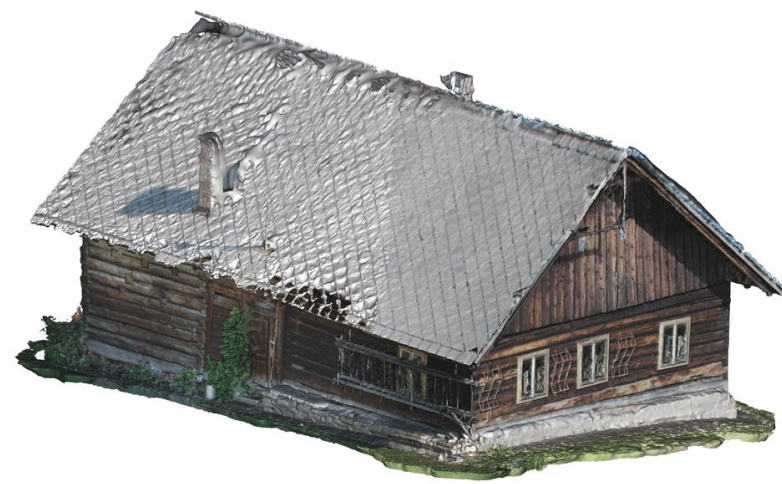

Figure 6. Example of the final DSM of the examined building, Vigantice (Vsetín dist.)

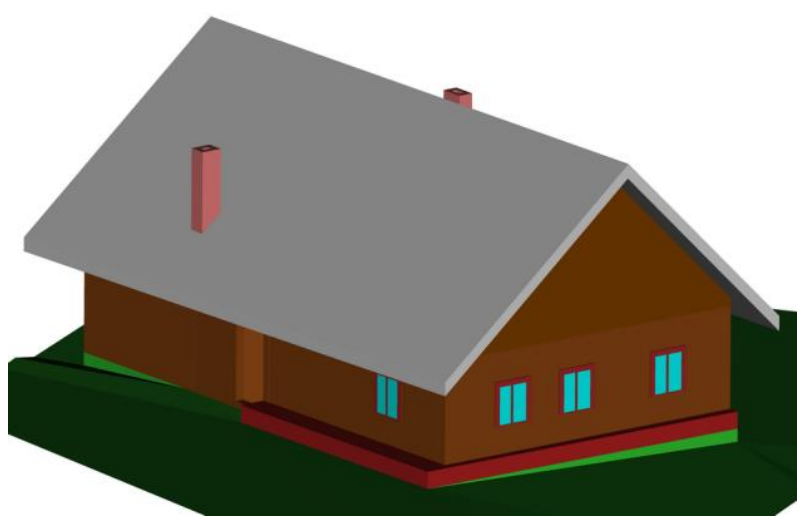

Figure 7. Example of the final 3D model of the examined building, Vigantice (Vsetín dist.)

On the other hand, both software platforms - MicroStation and Revit - allow to generate DEM from spatial points that can come from point clouds, detailed geodetic survey, GIS altimetry analysis (Czech Office for Surveying, Mapping and Cadastre, 2010) and so on.

The Level of Detail (LoD) of the final - 3D model and BIModel - should match the LoD of the metric survey documentation that the model is made of and the purpose, it is intended to serve. For metric survey documentation is usually used as the starting reference scale 1: 50 (Tommasi et al., 2016; Veselý, 2014).

In the case of HBIM, the final BIModel should have customized the LoD of descriptive attributes for each model component to match its geometric LoD. 


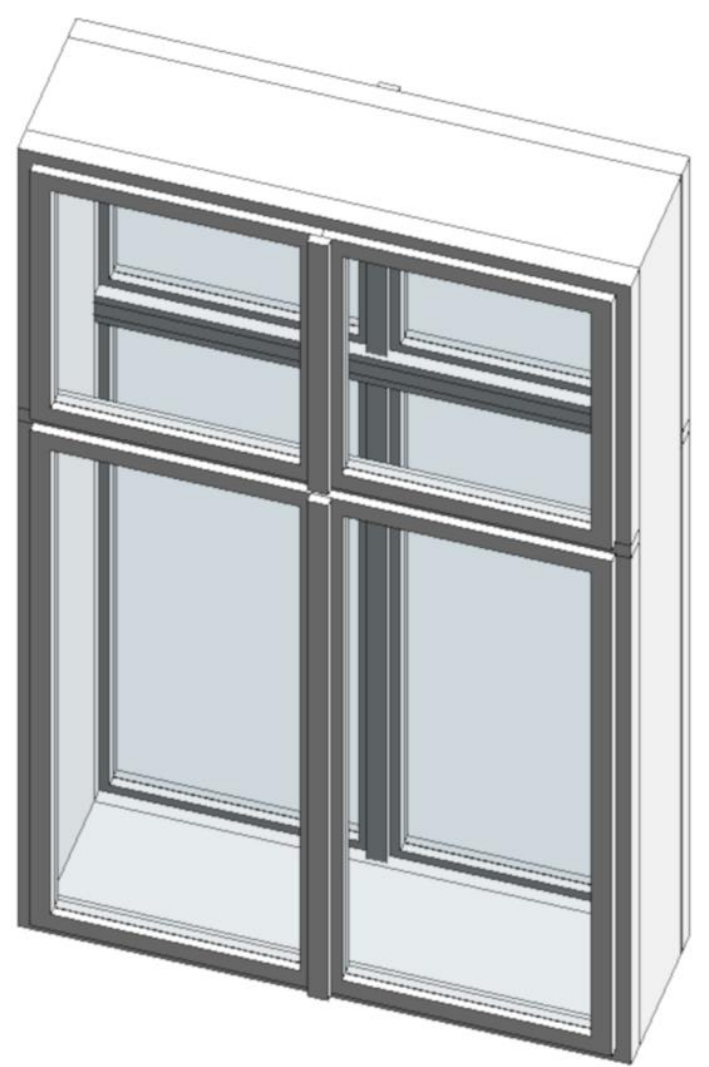

Figure 8. Example of the HBIM component - double lining window

\section{CONCLUSIONS}

This paper presents practical experience gained during the implementation of the grant project "The Transformation of Rural Architecture with Emphasis on the Development of the $19^{\text {th }}$ and $20^{\text {th }}$ Centuries", No. DG16P02H023, which aims to present the historical and artistic values of rural architecture as a national cultural heritage. The project includes a simplified metric survey documentation of examined rural buildings (Poloprutský, 2018). Subsequently, the 3D models of examined buildings are modeled on the basis of survey metric documentation.

At the beginning of the project, it was necessary to select workflows and technologies to process these 3D models. CAD approach and HBIM approach access were most seriously considered, see Chap. 2.2 and Chap. 2.3. Based on the comparison of both approaches, it was decided to prioritize the CAD approach, see Chap. 2.4.

The HBIM approach is most effective in cases:

- $\quad$ where one building is a subject of interest, i.e. its building parts may undergo a detailed survey (Tommasi et al., 2016)

- where multiple buildings of the same architectural style are subjects of interest (Baik et al., 2014)

This project is aimed at rural architecture, which is very diverse, for examples see Figure 1, Figure 2 and Figure 3. For its purpose, it was uneconomical to apply HBIM approach because it would be necessary to create a new library with components for each examined building. That approach is beyond the capabilities of the research team.

On the other hand, BIModel can find use in a detailed building survey, such as the Building Archaeology Survey, or as a basis for a building renovation project.

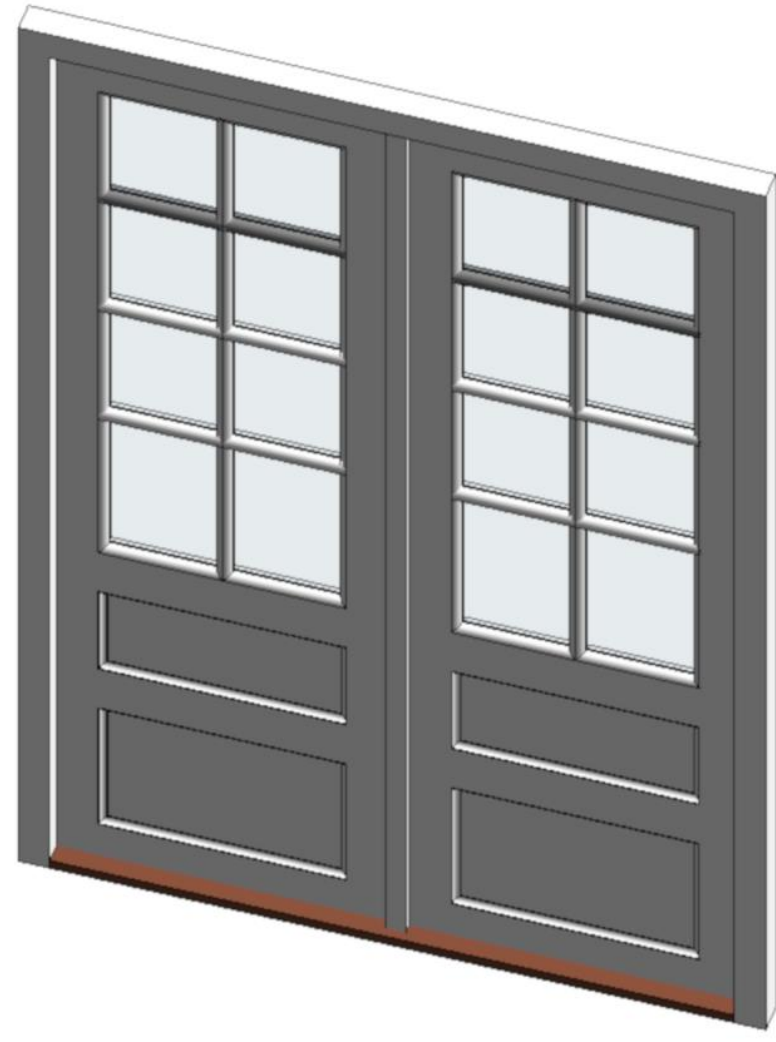

Figure 9. Example of the HBIM component - double-winged glass door

In any case, the creation of a 3D model or BIModel should be preceded by a consultation of their customer and creator. This start of cooperation helps to improve mutual communication and prevent future misunderstandings, as was the case with this project.

\section{ACKNOWLEDGEMENTS}

This work was supported by the Ministry of Culture of the Czech Republic from the Program for the Support of Applied Research and Development of National and Cultural Identity for the years 2016 to 2022 (NAKI II), grant project "The Transformation of Rural Architecture with Emphasis on the Development of the $19^{\text {th }}$ and $20^{\text {th }}$ Centuries", No. DG16P02H023. For more information about this project, visit the project website http://venkov.fsv.cvut.cz/projekt.

\section{REFERENCES}

Baik, A., Alitany, A., Boehm, J., Robson, S., 2014. Jeddah Historical Building Information Modelling "JHBIM" - Object Library. ISPRS Annals of Photogrammetry, Remote Sensing and Spatial Information Sciences, II-5, 41-47. doi.org/10.5194/isprsannals-II-5-41-2014

Beránek, J., Macek, P. (Eds.), 2015. Building Archaeology Survey: A Methodology. National Heritage Institute, Prague.

Bezděk, L., Frouz, M., 2014. Digitální a digitalizovaná fotografie pro vědecké účely v praxi památkové péče. National Heritage Institute, Prague. 
BIMe Initiative, 2017. BIM Dictionary. https://bimdictionary.com/ (10 June 2019).

Brejcha, M., Brůna, V., Marek, Z., Větrovská, B., 2015. Metodika digitalizace, $3 D$ dokumentace a $3 D$ vizualizace jednotlivých typů památek: certifikovaná metodika. Národní památkový ústav, územní odborné pracoviště v Ústí nad Labem a Filosofická fakulta University J. E. Purkyně v Ústí nad Labem, Ústí nad Labem.

Czech Office for Surveying, Mapping and Cadastre, 2016. Atom download service - test operation. http://atom.cuzk.cz/ (10 June 2019).

Czech Office for Surveying, Mapping and Cadastre, 2010. Geoportal ČÚZK: Access to map products and services. http://geoportal.cuzk.cz/(10 June 2019).

Hodač, J., Zemánková, A., 2018. HISTORICAL ORTHOPHOTOS CREATED ON BASE OF SINGLE PHOTOS - SPECIFICS OF PROCESSING. Stavebni obzor Civil Engineering Journal, 27, 425-438. doi.org/10.14311/CEJ.2018.03.0034

Hůrková, L., Mezihoráková, K. (Ed.), 2018. Proměny venkovské architektury s di̊razem na vývoj v 19. a 20. století I. Artefactum, Praha.

Hůrková, L., Mezihoráková, K., 2017. Průzkum a identifikace památkových hodnot venkovské architektury 19. a 20. století v bývalé vsi Dušníky (Rudná): Workshop studentů Fakulty architektury $\check{C} V U T$. Artefactum, Praha.

Hůrková, L., Mezihoráková, K., 2016. House with a Column Arcade in Ropice, Památky Těšinského knižectví. Artefactum, Prague, 179-191.

Luhmann, T., Robson, S., Kyle, S., Boehm, J., 2014. Closerange photogrammetry and $3 \mathrm{D}$ imaging, 2nd edition. De Gruyter textbook. De Gruyter, Berlin.

Poloprutský, Z., 2018. METRIC SURVEY DOCUMENTATION AS A BASIS FOR UNDERSTANDING THE DEVELOPMENT OF RURAL ARCHITECTURE. Stavebni obzor - The Civil Engineering Journal, 27, 48-59. doi.org/10.14311/CEJ.2018.01.0005

Poloprutský, Z., Soukup, P., Gruber, J., 2017. Development of rural settlements in the 19th and 20th centuries: creation of analytical map outputs, DËJINY STAVEB 2017. Klub Augusta Sedláčka, Pilsen, Czech Republic, 235-243.

Tommasi, C., Achille, C., Fassi, F., 2016. FROM POINT CLOUD TO BIM: A MODELLING CHALLENGE IN THE CULTURAL HERITAGE FIELD. ISPRS - International Archives of the Photogrammetry, Remote Sensing and Spatial Information Sciences, XLI-B5, 429-436. doi.org/10.5194/isprsarchives-XLI-B5-429-2016

Veselý, J., 2014. Metric survey documentation of historic buildings for use in heritage management. National Heritage Institute, Prague.

Vlček, P., 2017. Vesnička tesařů Ostrovec (Johannesdörfl), Památky Západních Čech VI/VII-2016/2017. Národní památkový ústav, územní odborné pracoviště v Plzni, Plzeň. 39-46.

Revised June 2019 